\title{
Detection of monoclonal immunoglobulin heavy chain gene rearrangement (FR3) in Thai malignant lymphoma by High Resolution Melting curve analysis
}

Tanawan Kummalue*1, Anchalee Chuphrom', Sanya Sukpanichnant² ${ }^{2}$ Tawatchai Pongpruttipan² and Sathien Sukpanichnant ${ }^{1}$

\begin{abstract}
Malignant lymphoma, especially non-Hodgkin lymphoma, is one of the most common hematologic malignancies in Thailand. The diagnosis of malignant lymphoma is often problematic, especially in early stages of the disease. Detection of antigen receptor gene rearrangement including T cell receptor (TCR) and immunoglobulin heavy chain (IgH) by polymerase chain reaction followed by heteroduplex has currently become standard whereas fluorescent fragment analysis (GeneScan) has been used for confirmation test. In this study, three techniques had been compared: thermocycler polymerase chain reaction (PCR) followed by heteroduplex and polyacrylamide gel electrophoresis, GeneScan analysis, and real time PCR with High Resolution Melting curve analysis (HRM). The comparison was carried out with DNA extracted from paraffin embedded tissues diagnosed as B-cell non-Hodgkin lymphoma. Specific PCR primers sequences for $\mathrm{lg} \mathrm{H}$ gene variable region 3 , including fluorescence labeled $\mathrm{lgH}$ primers were used and results were compared with HRM. In conclusion, the detection IgH gene rearrangement by HRM in the LightCycler System showed potential for distinguishing monoclonality from polyclonality in B-cell non-Hodgkin lymphoma.
\end{abstract}

\section{Introduction}

Malignant lymphoma, especially non-Hodgkin lymphoma, is one of the most common hematologic malignancies in Thailand. The incidence rate as reported by Ministry of Public Health is 3.1 per 100,000 population in female whereas the rate in male is 4.5 per 100,000 population [1]. At Siriraj Hospital, the new cases diagnosed as malignant lymphoma were 214.6 cases/year [2]. The diagnosis of malignant lymphoma is often problematic, especially in early stages of the disease. Therefore, detection of antigen receptor gene rearrangement including $T$ cell receptor (TCR) and immunoglobulin heavy chain $(\mathrm{lgH})$ by polymerase chain reaction $(\mathrm{PCR})$ assay has recently become a standard laboratory test for discrimination of reactive from malignant clonal lymphoproliferation [3,4]. Analyzing DNA extracted from formalin-fixed, paraffin-embedded tissues by multiplex PCR techniques is more rapid, accurate and highly sensitive. Measuring the size of the amplicon from PCR analysis could be used to diagnose malignant lymphoma with monoclonal pattern showing specific and distinct bands detected on acrylamide gel electrophoresis. However, this technique has some limitations and some patients might require a further confirmation test such as GeneScan or fragment analysis [5,6].

GeneScan technique or fragment analysis reflects size and peak of DNA by using capillary gel electrophoresis. This technique is highly sensitive and can detect $0.5-1 \%$ of clonal lymphoid cells. It measures the amplicons by using various fluorescently labeled primers at forward or reverse sides and a specific size standard. Using a Genetic Analyzer machine and GeneMapper software (Applied Bioscience, USA), the monoclonal pattern revealed one single, sharp and

* Correspondence: sitkm@mahidol.ac.th

1 Department of Clinical Pathology, Faculty of Medicine Siriraj Hospital, Bangkok 10700, Thailand

Full list of author information is available at the end of the article

(c) 2010 Kummalue et al; licensee BioMed Central Ltd. This is an Open Access article distributed under the terms of the Creative ComBHWed Central mons Attribution License (http://creativecommons.org/licenses/by/2.0), which permits unrestricted use, distribution, and reproduction in any medium, provided the original work is properly cited. 
high peak at the specific size corresponding to acrylamide gel pattern, whereas the polyclonal pattern showed multiple and small peak condensed th the same size standard. This technique is the most sensitive and accurate technique; however, it usually requires high technical experience and is also of high cost [7]. Therefore, rapid and more cost effective technique are being sought.

LightCycler PCR performs the diagnostic detection of amplicon via melting curve analysis within 2 hours with the use of a specific dye $[8,9]$. This dye consists of two types: one known as SYBR-Green I which is non specific and the other named as High Resolution Melting analysis (HRM) which is highly sensitive, more accurate and stable. Several reports demonstrated that this new instrument combined with DNA intercalating dyes can be used to discriminate sequence changes in PCR amplicon without manual handling of PCR product [10,1 1]. Therefore, current investigations using melting curve analysis are being developed [12,13].

In this study, three different techniques were compared to evaluate the suitability of LightCycler PCR with HRM as the clonal diagnostic tool for IgH gene rearrangement in B-cell non-Hogdkin lymphoma, i.e. thermocycler PCR followed by heteroduplex analysis and PAGE, GeneScan analysis and LightCycler PCR with HRM.

\section{Materials and methods Patients}

Twenty-six cases of B-cell non-Hodgkin lymphoma diagnosed by hematopathologists from Department of Pathology, Faculty of Medicine Siriraj Hospital, Mahidol University, were enrolled in this study. The diagnosis of B-cell non-Hodgkin lymphoma followed the WHO classification 2008 by using morphological and immunophenotypical features. This study was approved by the Siriraj Institutional Review Board, Faculty of Medicine Siriraj Hospital, Mahidol University.

\section{DNA extraction}

Serial $10 \mu \mathrm{m}$ thick sections were obtained with a standard microtome and disposable blades from paraffin embedded lymph nodes. In brief, waxes were extracted with xylene followed by centrifugation at $6000 \mathrm{~g}$ for $10 \mathrm{~min}$ utes. After this initial step, pellets were resuspended in absolute ethanol for 5 minutes and centrifuged. Paraffinfree tissue was dried with heating box for 15 minutes at $37^{\circ} \mathrm{C}$ and subjected to the DNA extraction procedures using QIAamp DNA mini kit (Qiagen). The concentration of DNA was measured with Smartspect (BIO-RAD, USA).

\section{PCR primers and thermalcycler program}

PCR primers sequences for IgH variable gene framework region 3 (FR3) plus joining region (JH) consensus primers were designed followed BIOMED-2 [14]. These primers were designed to target conserved DNA sequences surrounding the unique hypervariable anigen-binding complementarity determining region 3 (CDR3). To amplify the IgH variable region in Thermalcycler (BIO-RAD, USA), genomic DNA at 800-1000 ng. was added up to a final reaction $50 \mu \mathrm{l}$. After the initial "hot start" using Faststart (Roche Diagnostic) at $95^{\circ} \mathrm{C}$ for 7 minutes, PCR cycle program included: denaturing at $95^{\circ} \mathrm{C}$ for 45 seconds, followed by annealing at $60^{\circ} \mathrm{C}$ for 45 seconds, and extension at $72^{\circ} \mathrm{C}$ for 90 seconds. The program was repeated for 34 cycles. A final extension was performed at $72^{\circ} \mathrm{C}$ for 10 minutes.

\section{Heteroduplex analysis}

For heteroduplex analysis, the PCR products $20 \mu \mathrm{l}$ were denatured at $95^{\circ} \mathrm{C}$ for 5 minutes, and then rapid random renaturation at $4^{\circ} \mathrm{C}$ for 1 hour. Heteroduplex were detected by polyacrylamide gel electrophoresis (PAGE) on an $6 \%$ non-denaturing acrylamide gel $(16 \times 16 \times 0.1$ $\mathrm{cm}$ ) using SE600 Ruby (Amersham Bioscience, USA) at room temperature for 210 minutes at 110 Volts. The gel was then stained with $0.5 \mu \mathrm{g} / \mathrm{ml}$ ethidium bromide and photographed under ultraviolet light using ChemiDoc $^{\mathrm{Tn}}$ XRS System (BIO-RAD, USA). PCR and heteroduplex analysis were performed in duplicate.

\section{LightCycler PCR and High Resolution Melting curve analysis (HRM)}

The PCR product of IgH variable region 3 was further amplified in the LightCycler System 480 (Roche Diagnostic). The reaction mixture for each well contained high resolution melting master $10 \mu \mathrm{l}, 5 \mathrm{pmol} / \mu \mathrm{l}$ of IgH (FR3) primer $2 \mu \mathrm{l}, 25 \mathrm{mM}$ of $\mathrm{MgCl}_{2} 2.4 \mu \mathrm{l}, \mathrm{dH}_{2} \mathrm{O}$ PCR grade 4.6 $\mu \mathrm{l}$, and diluted 1:100 PCR product $1 \mu \mathrm{l}$, was added up to a final volume of $20 \mu \mathrm{l}$. After the initial "hot start", PCR cycle parameters were held at pre-incubator $95^{\circ} \mathrm{C}$ for 10 minutes, and amplification program was $95^{\circ} \mathrm{C} 10$ second, $55^{\circ} \mathrm{C} 15$ seconds, and $72^{\circ} \mathrm{C} 15$ seconds. High resolution melting program was $95^{\circ} \mathrm{C} 1$ minute, $55^{\circ} \mathrm{C} 1$ minute, $70^{\circ} \mathrm{C}$ 1 second. After the 30 PCR amplification cycles, the LightCycler System DNA melting curve was analysed by LightCycler 480 software. All samples were performed in duplicate.

\section{Fluorescent fragment analysis (GeneScan)}

For GeneScan analysis, the PCR product was carried out using the conditions mentioned above with fluorescence labeled primers. The sequences of fluorescence labeled IgH primers were as follows: 
Table 1: Summary of cases analyzed by PAGE, GensScan and LightCycler.

\begin{tabular}{|c|c|c|c|c|c|c|}
\hline Patient & Age/Sex & Tissues & Diagnosis & GeneScan & HRM & $\%$ tumor/B cell* \\
\hline 1 & $58 / F$ & Thyroid gland & Diffuse large B cell & Monoclonal H = 8818 & $\begin{array}{l}\text { Monoclonal Tm = } \\
84.83\end{array}$ & 90 \\
\hline 2 & $46 / M$ & Lymph node & Diffuse large B cell & Monoclonal H=8575 & $\begin{array}{l}\text { Monoclonal } \mathrm{Tm}= \\
85.18\end{array}$ & 95 \\
\hline 3 & $51 / F$ & $\begin{array}{l}\text { Soft tissue, } \\
\text { submandibular }\end{array}$ & Diffuse large B cell & Monoclonal H = 8814 & $\begin{array}{l}\text { Polyclonal Tm = } \\
83.42 / 86.85\end{array}$ & 95 \\
\hline 4 & $77 / F$ & Lymph node & Diffuse large B cell & Monoclonal H = 7831 & $\begin{array}{l}\text { Monoclonal } \mathrm{Tm}= \\
88.33\end{array}$ & 90 \\
\hline 5 & $49 / M$ & Stomach & Diffuse large B cell & Monoclonal H = 9008 & $\begin{array}{l}\text { Monoclonal } \mathrm{Tm}= \\
86.04\end{array}$ & 90 \\
\hline 6 & $63 / F$ & Lymph node & Diffuse large B cell & Monoclonal H = 7759 & $\begin{array}{l}\text { Polyclonal Tm = } \\
83.26 / 88.62\end{array}$ & 75 \\
\hline 7 & $68 / M$ & Lymph node & Diffuse large B cell & Monoclonal H = 8405 & $\begin{array}{l}\text { Monoclonal Tm = } \\
85.59\end{array}$ & 95 \\
\hline 8 & $42 / \mathrm{M}$ & Lymph node & Diffuse large B cell & Monoclonal H = 6731 & $\begin{array}{l}\text { Monoclonal Tm = } \\
86.06\end{array}$ & 90 \\
\hline 10 & $58 / \mathrm{M}$ & Skin & Diffuse large B cell & Monoclonal H=8060 & $\begin{array}{l}\text { Monoclonal Tm= } \\
86.36\end{array}$ & 95 \\
\hline 11 & $68 / F$ & Lymph node & Diffuse large B cell & Monoclonal H=8005 & $\begin{array}{l}\text { Monoclonal Tm = } \\
87.24\end{array}$ & 90 \\
\hline 12 & $35 / F$ & Tonsil & Follicular lymphoma & Monoclonal H = 8738 & $\begin{array}{l}\text { Monoclonal Tm = } \\
88.85\end{array}$ & 90 \\
\hline 13 & $70 / F$ & Lacrimal gland & $\begin{array}{l}\text { Extranodal marginal } \\
\text { zone B cell }\end{array}$ & Monoclonal H=8122 & $\begin{array}{l}\text { Monoclonal Tm = } \\
80.62\end{array}$ & 95 \\
\hline 14 & $61 / M$ & Lymph node & Follicular lymphoma & Monoclonal H = 6887 & $\begin{array}{l}\text { Polyclonal Tm = } \\
84.00 / 87.01\end{array}$ & 75 \\
\hline 15 & $67 / F$ & Lymph node & Marginal zone B cell & Monoclonal H = 7862 & $\begin{array}{l}\text { Monoclonal Tm = } \\
86.10\end{array}$ & 80 \\
\hline 16 & $72 / \mathrm{M}$ & Tonsil & $\begin{array}{l}\text { Extranodal marginal } \\
\text { zone B cell }\end{array}$ & Monoclonal H= 7004 & $\begin{array}{l}\text { Monoclonal Tm = } \\
86.15\end{array}$ & 95 \\
\hline 17 & $13 / M$ & omentum & Burkitt lymphoma & Monoclonal H = 7936 & $\begin{array}{l}\text { Monoclonal TM= } \\
86.48\end{array}$ & 99 \\
\hline
\end{tabular}


Table 1: Summary of cases analyzed by PAGE, GensScan and LightCycler. (Continued)

\begin{tabular}{|c|c|c|c|c|c|c|}
\hline 18 & $67 / F$ & Soft tissue, cheek & $\begin{array}{l}\text { Extranodal marginal } \\
\text { zone B cell }\end{array}$ & Monoclonal $\mathrm{H}=8186$ & $\begin{array}{l}\text { Monoclonal Tm = } \\
86.34\end{array}$ & 95 \\
\hline 19 & $60 / F$ & Lymph node & Diffuse large B cell & Monoclonal $\mathrm{H}=7805$ & $\begin{array}{l}\text { Monoclonal Tm = } \\
86.8\end{array}$ & 99 \\
\hline 20 & $79 / F$ & Lymph node & $\begin{array}{l}\text { Marginal zone B cell } \\
\text { lymphoma }\end{array}$ & Monoclonal $\mathrm{H}=9120$ & $\begin{array}{l}\text { Monoclonal Tm = } \\
87.29\end{array}$ & 90 \\
\hline 21 & $75 / M$ & Thyroid gland & $\begin{array}{l}\text { Extranodal marginal } \\
\text { zone B cell }\end{array}$ & Monoclonal $\mathrm{H}=8418$ & $\begin{array}{l}\text { Monoclonal } \mathrm{Tm}= \\
87.37\end{array}$ & 90 \\
\hline 22 & $73 / F$ & Soft tissue, neck & Diffuse large B cell & Monoclonal H = 7921 & $\begin{array}{l}\text { Monoclonal Tm = } \\
85.59\end{array}$ & 95 \\
\hline 23 & $55 / M$ & Lymph node & Burkitt lymphoma & Monoclonal $\mathrm{H}=8423$ & $\begin{array}{l}\text { Monoclonal Tm = } \\
86.03\end{array}$ & 99 \\
\hline 24 & $72 / F$ & Nasal cavity & Diffuse large B cell & Monoclonal $\mathrm{H}=8974$ & $\begin{array}{l}\text { Monoclonal Tm = } \\
85.55\end{array}$ & 98 \\
\hline 25 & $\mathrm{~N} / \mathrm{M}$ & Lymph node & Diffuse large B cell & Monoclonal $\mathrm{H}=7742$ & $\begin{array}{l}\text { Monoclonal Tm = } \\
88.44\end{array}$ & 95 \\
\hline 26 & $63 / F$ & Lymph node & Follicular lymphoma & Monoclonal H = 8977 & $\begin{array}{l}\text { Monoclonal Tm = } \\
87.14\end{array}$ & 90 \\
\hline
\end{tabular}

HVF3-3FL 5'-TCTGCAAATGAACAGCCTGAGAG CC-3' Dye-label 5' VIC,

HVF4-3FL 5'-GAGCTCTGTGACCGCCGCGGACAC G-3' Dye-label 5' VIC,

HVF5-3FL 5'-CAGCACCGCCTACCTGCAGTGGAG C-3' Dye-label 5' NED,

HVF6-3FL 5'-GTTCTCCCTGCAGCTGAACTCTGT G-3' Dye-label 5' NED,

HVF7-3FL 5'-CAGCACGGCATATCTGCAGATCAG3' Dye-label 5' PET,

HDF1-3FL 5'-TGGAGCTGAGCAGCCTGAGATCT GA-3' Dye-label 5' 6FAM, and HVF2-3FL 5'-CAATGACCAACATGGACCCTGTGGA-3' Dye-label 5' 6FAM. The amplified fragments were analyzed by ABI 3130 Genetic Analyzer (Applied Bioscience, USA) according to the manufacturer's protocol. In brief, each sample contained $1 \mu \mathrm{l}$ of the PCR product mixed with $10.7 \mu \mathrm{l}$ of $\mathrm{Hi}-\mathrm{Di}$ formamide and $0.3 \mu \mathrm{l}$ of $600 \mathrm{LIZ}^{\circ}$ size standard (Applied bioscience, USA). Samples were denatured at $95^{\circ} \mathrm{C}$ for 5 minutes and immediately chilled on ice for 2 minutes. The gel used for capillary electrophoresis was POP-4 polymer solution (Applied Bioscience, USA). Results were visualized using the ABI GeneMapper v 3.2 software (Applied Bioscience, USA). The expected size varied from 100-170 bp.

\section{Results}

Patients characteristics

Age of the patients in this study ranged from 13 to 79 years. As shown in Table 1, of 26 patients enrolled in this study, 2 patients were diagnosed as Burkitt lymphoma (BL), 4 cases were extranodal marginal zone lymphoma of mucosa-associated lymphoid tissue (MALT) lymphoma, 3 cases were follicular lymphoma (FL), 2 cases were nodal marginal zone lymphoma, and the other 15 cases were diffuse large B cell lymphoma (DLBCL). From previous report, the 5 most common types of B-cell non Hodgkin lymphoma in Thailand are DLBCL, FL, MALT lymphoma, BL, and small lymphocytic lymphoma (SLL)[2]. Therefore, this finding is in accordance with the distribution that was observed before. Percentage of lymphoma 


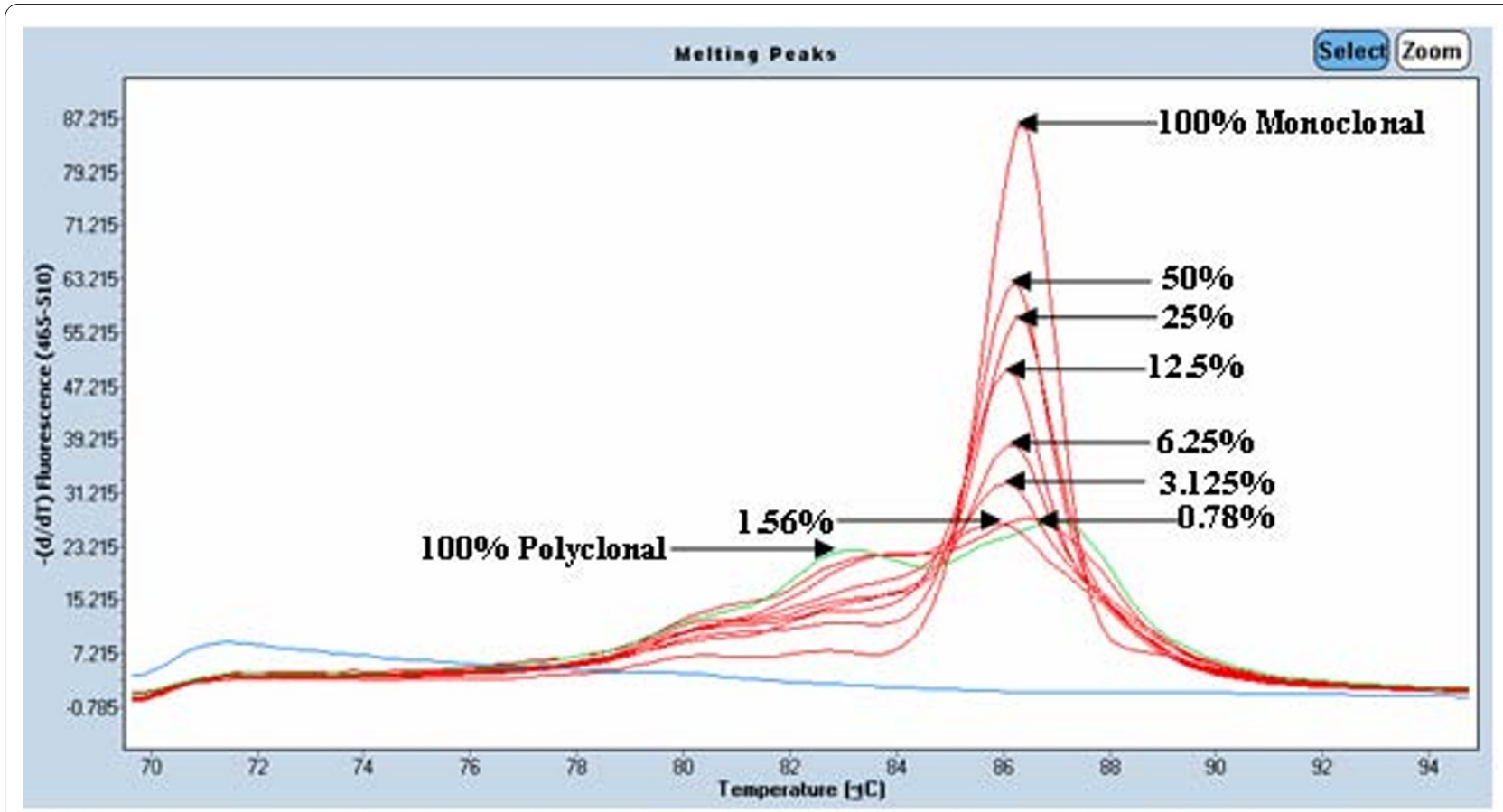

Figure 1 Detection limit of LightCycler System using melting curve analysis. DNA of positive sample was diluted with tonsil DNA into 50\%, 25\%, $12.5 \%, 6.25 \%, 3.125 \%, 1.56 \%$, and $0.78 \%$. At the percentage equal to 0.78 , Tm was still detected as monoclone.

involvement within each specimen was demonstrated in the Table 1.

\section{High Resolution Melting curve analysis and lower limit for} detecting monoclonal IgH gene rearrangement

The optimal number of PCR cycles was evaluated using monoclonal sample and polyclonal sample from positive lymph node and tonsil, respectively. Based on previous report, 30 cycles of LightCycler PCR showed the Tm with peak height at least twice as high, and less than one half as wide as a polyclonal tonsil sample. Therefore, the number of PCR at 30 cycles was used to investigate in this study [15].

To evaluate the minimum detectable percentage of $\operatorname{IgH}$ monoclonal DNA with melting curve analysis, serial dilu-

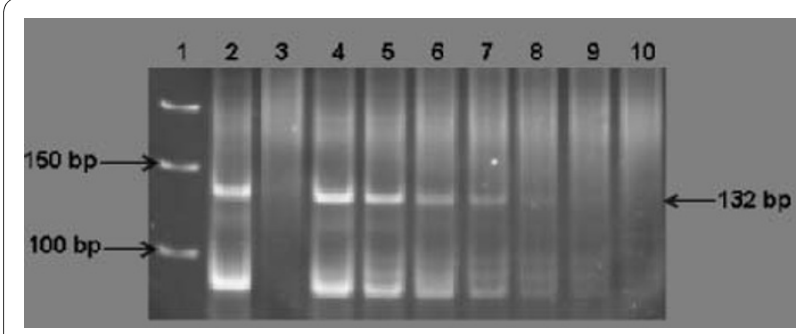

Figure 2 Minimal detection of polyacrylamide gel electrophoresis analysis and ethidium bromide staining of monoclonal $\lg \mathrm{H}$ gene rearrangement. The distinct band consistent with monoclonal IgH gene rearrangement could be detected at concentration as low as 3.125\%. Lane 1 = GeneRuler 50 bp DNA ladder marker, Lane $2=$ positive control, Lane $3=$ negative control, Lane $4-10=$ serial dilutions 50\%, $25 \%, 12.5 \%, 6.25 \%, 3.125 \%, 1.56 \%$, and $0.78 \%$, respectively. tions of IgH tube $\mathrm{C}$ monoclone with polyclone at various percentages of $50 \%, 25 \%, 12.5 \%, 6.25 \%, 3.125 \%, 1.56 \%$, and $0.78 \%$ were performed. After 30 cycles in LightCycler, Tm at a percentage equal $0.78 \%$ was still detected as monoclonal group by melting curve analysis as shown in Figure 1. For PAGE, one discrete band at specific size could be detected at concentration $3.125 \%$ whereas a distinct peak in GeneScan was clearly demonstrated at concentration as low as $0.78 \%$ as shown in Figure 2, Figure 3 and Figure 4.

\section{Comparison of PAGE and GeneScan}

All 26 IgH monoclonal samples showed a sharp band on ethidium bromide stained acrylamide gel with 100-170 bp as demonstrated in Figure 5. In GeneScan, all DNA monoclonal samples showed products of IgH which were characterized by 1 or 2 dominant peaks in the GeneScan profile, indicating the presence of $\mathrm{B}$ cell clonal proliferation as shown in Figure 6. As a result, all 26 samples in this study were confirmed to be monoclonality by GeneScan analysis.

\section{Comparison of GeneScan and High Resolution Melting curve analysis}

Comparing GeneScan versus High Resolution Melting curve analysis was performed. In the melting curve analysis by HRM, 23 samples demonstrated a high and narrow DNA melting curve that was greater twice the peak height but less than one half the width, when compared with the polyclonal sample as shown in Figure 7. Notably, 


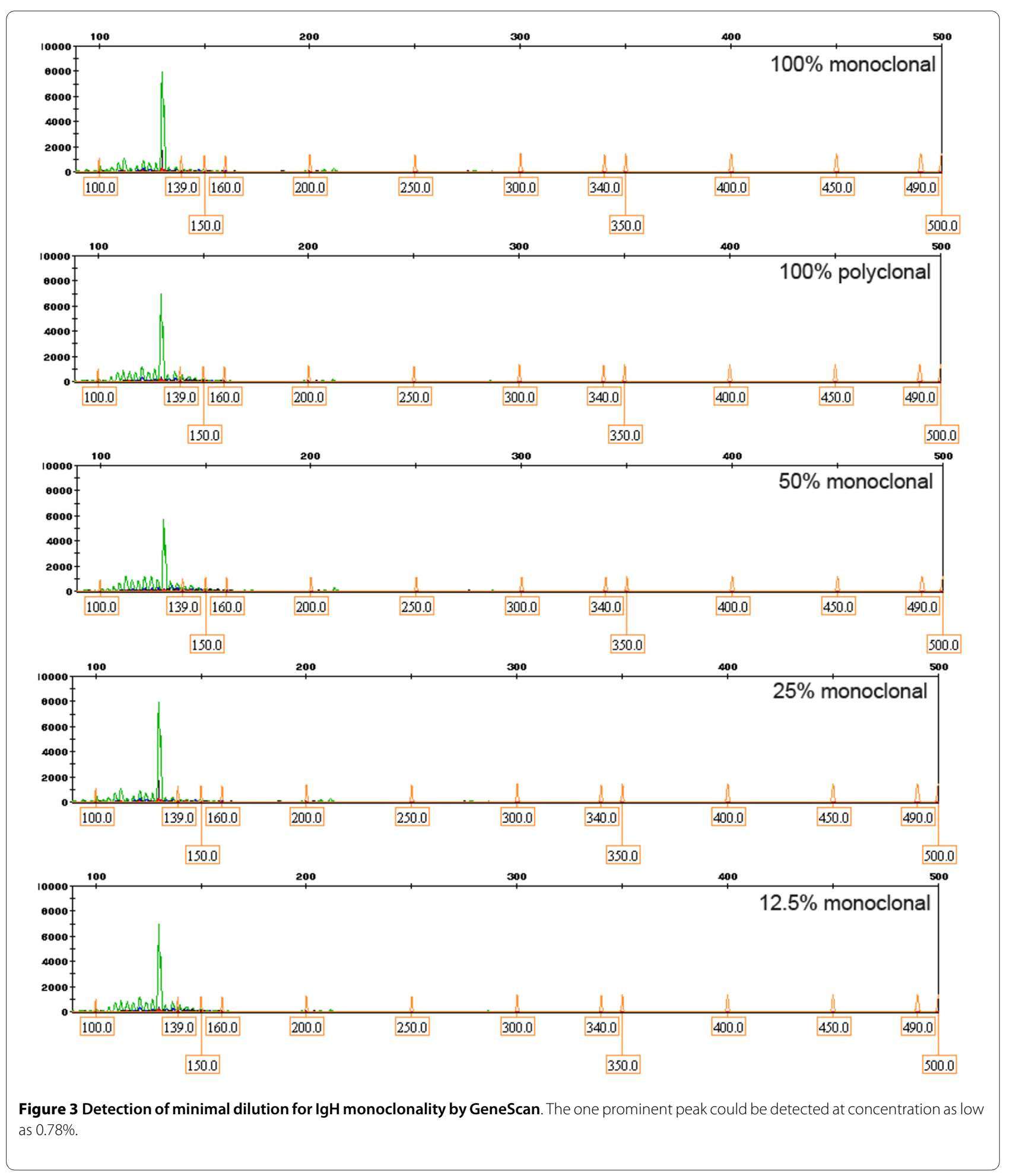




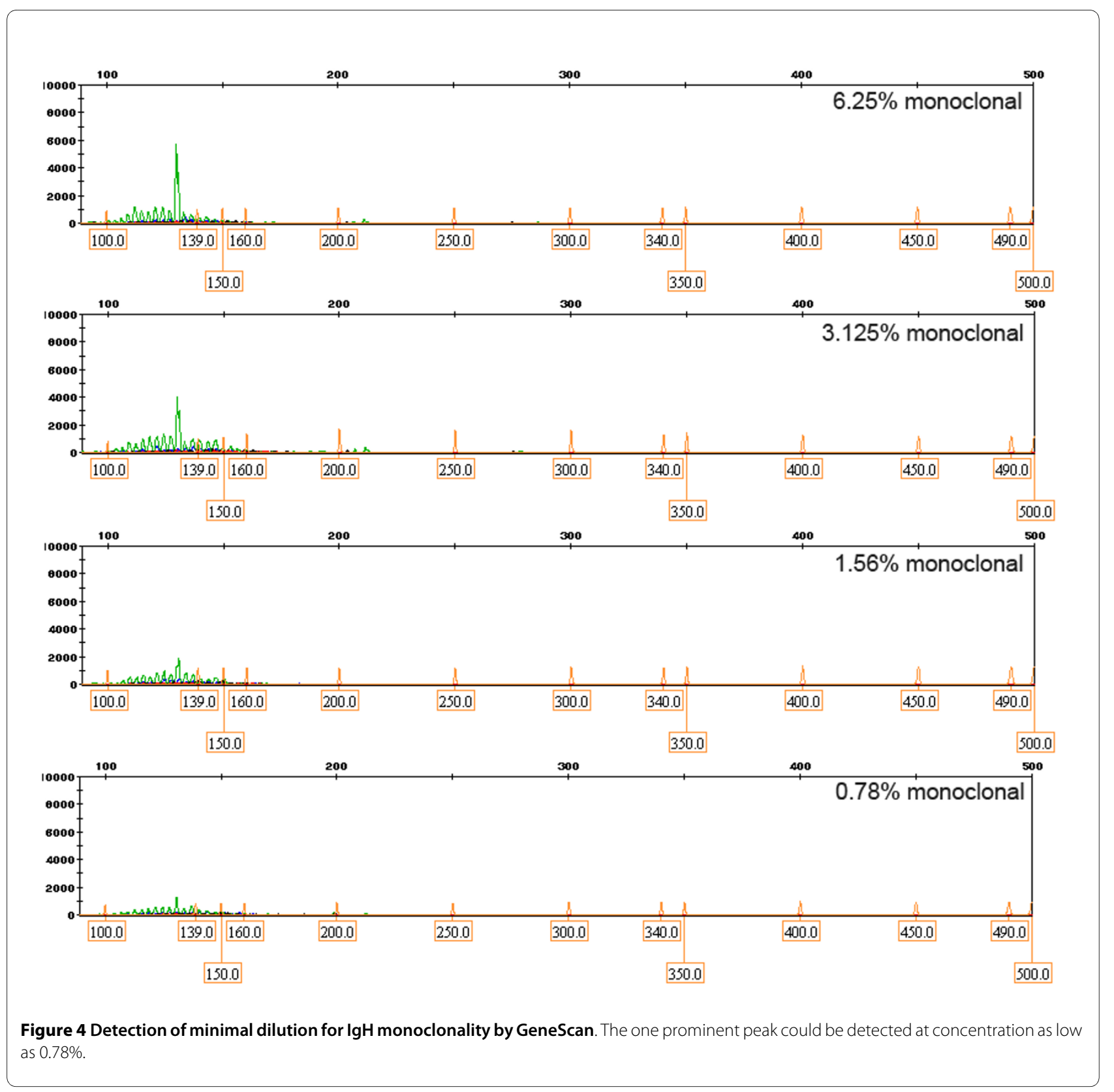

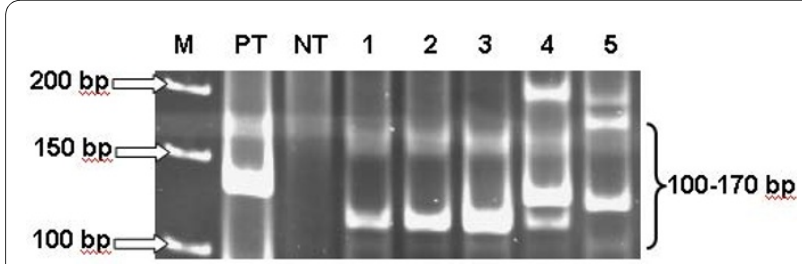

Figure $5 \mathrm{IgH}$ gene rearrangement showing the distinct band at 100-170 bp on ethidium bromide stained acrylamide gel. (arrow) $\mathrm{M}=$ GeneRuler 50 bp DNA Ladder Marker (Fermentas), PT = Positive control, NT = Negative control, 1-5 = Patients samples.
3 samples showed polyclonal pattern in melting curve analysis.

\section{Discussion}

Immunoglobulin heavy chain gene rearrangement has been widely used for diagnosis of B cell monoclonality [16]. At present, detection of monoclonal B cell population is based on heteroduplex including fluorescent PCR with GeneScan analysis. Recently, melting curve analysis (Tm) of duplex DNA has been applied to distinquish the monoclonal from polyclonal population. In this study, three techniques: thermocycler PCR followed by hetero- 

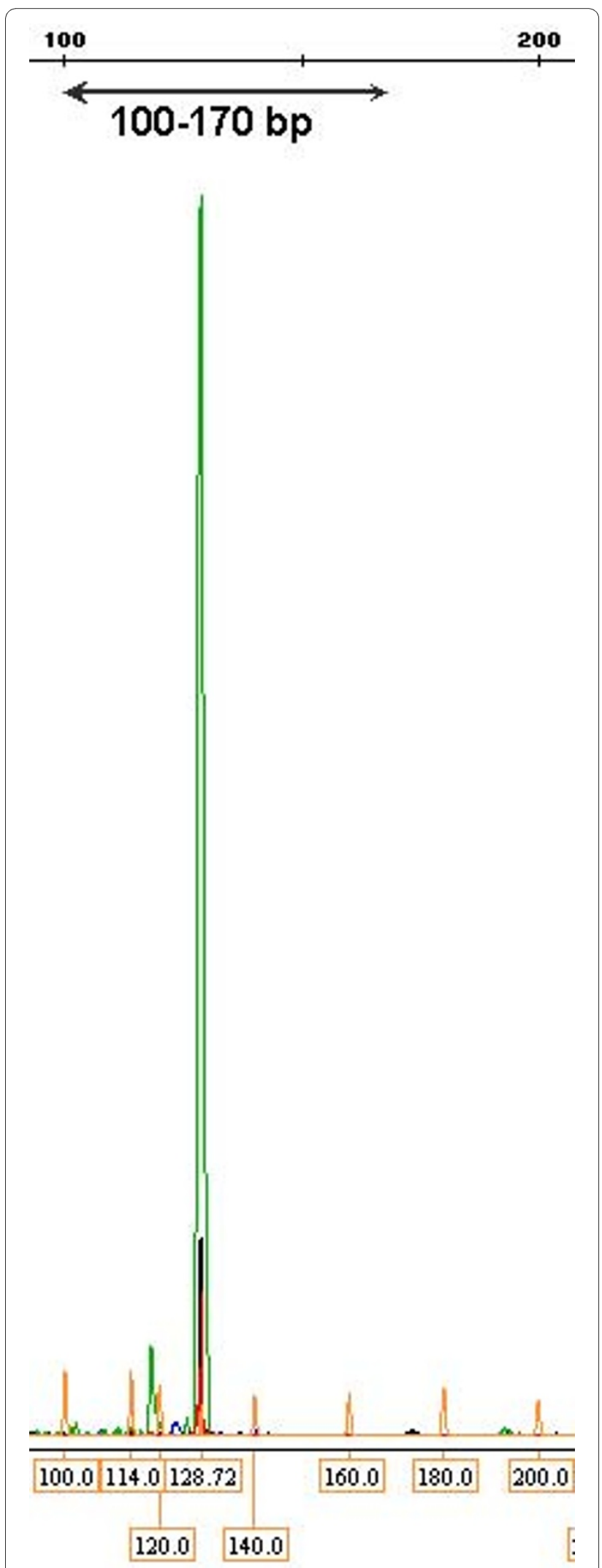

Figure 6 GeneScan analysis of IgH monoclonal sample revealed 1 dominant peak in the profile showing the monoclonal pattern. duplex and PAGE, GeneScan analysis and LightCycler PCR with HRM, were investigated in terms of detecting monoclonal immunoglobulin heavy chain variable gene framework region 3 (FR3).

From melting temperature of duplex DNA, 3 samples accounting for $11.5 \%$ revealed false negative by expressing polyclonality when compared with GeneScan. No false positive was detected in our series. From a previous report, using PCR-MCA (LightCycler Technology with high-speed amplification, and Idaho-Technology with rapid and high-resolution melting curve analysis -MCA) showed high sensitivity and specificity at $89.2 \%$ and $100 \%$ respectively [17]. Another study of 10 gastric MALT lymphomas using melting curve analysis with SYBR Green I showed similar sensitivity and specificity at $95.2 \%$ and $100 \%$, respectively [18]. This investigation also demonstrated high sensitivity as compared to other reports. The detection of the minimum percentage of monoclonality by HRM in our series was at $0.78 \%$ dilution which was higher than previous report [18]. 88.5\% sensitivity and $100 \%$ specificity were revealed in HRM indicating that a positive result in this method is specific for IgH monoclonality, whereas sensitivity and specificity of PAGE and GeneScan were considered as $100 \%$.

LightCycler technology has been used in many areas of clinical testing because of its rapid turn around time and accuracy. High Resolution Melting curve analysis, which is faster, simpler and less expensive, was developed as the latest method for product analysis in molecular diagnostics $[19,20]$. As compared all three methods concerning quality and accuracy, GeneScan with specific fluorescence labeled primers and HRM could detect the minimum level as low as $0.78 \%$. However, GeneScan has the highest cost which is approximately 3 times higher when compared with PAGE, and about 2 times when compared with HRM. In conclusion, based on our study, High Resolution Melting curve analysis in LightCycler System still has a potential role for clinically demonstrating monoclonal IgH.

\section{Competing interests}

The authors declare that they have no competing interests.

\section{Authors' contributions}

TK designed the experiments, controlled the overall project, and wrote the manuscript. AC carried out the experiments. SS 2 and TP participated in sending the tissue blocks. SS supported some instruments. All authors read and approved the final manuscript.

\section{Acknowledgements}

We would like to thank Assistant Professor Dr. Sathien Sukpanichnant, Head of Department of Clinical Pathology, Faculty of Medicine Siriraj Hospital, Mahidol University, Bangkok, Thailand, for his kind support. We also gratefully thank Ms. Penporn Sujiwattanarat, Ms. Maytinee Kladmuk, and Mr. Piyapat Pin-on for their helpful technical support. This study was funded by Mahidol University, Bangkok, Thailand. 


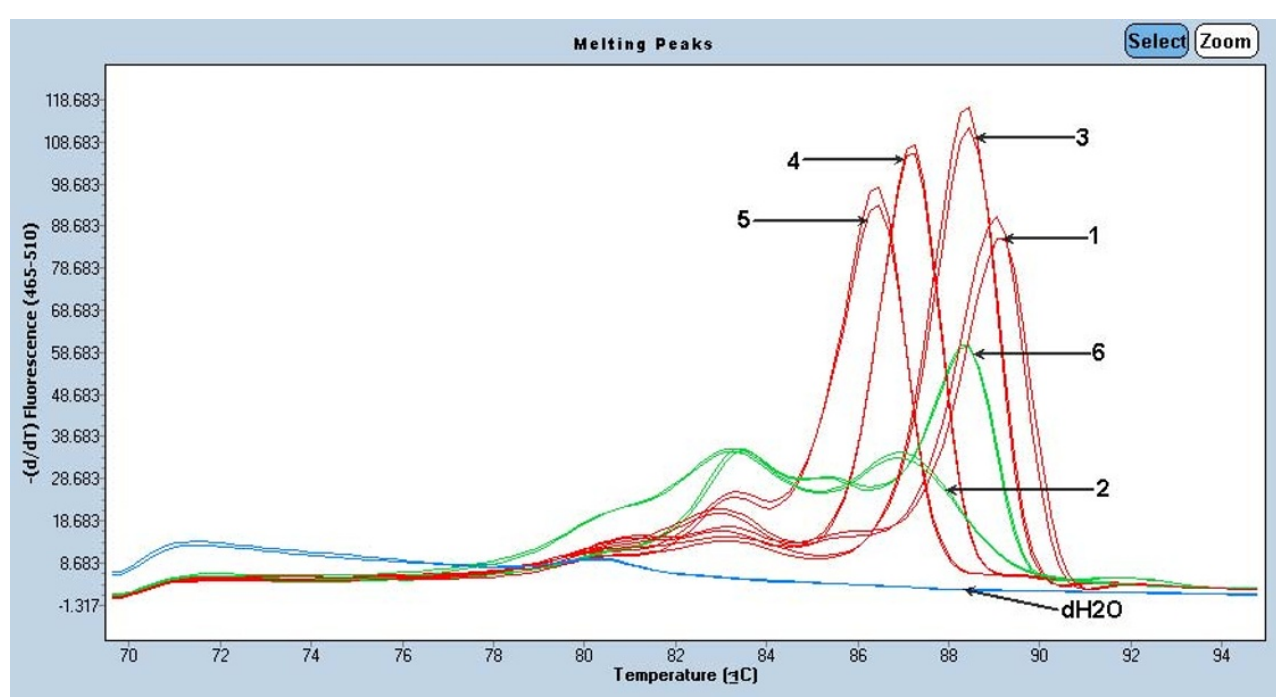

Figure 7 Demonstrated melting curve analysis in IgH malignant lymphoma using LightCycler System. (arrow) $1=$ positive monoclone, $2=$ neg ative polyclone, 3 = patient sample (monoclone), 4 = patient sample (monoclone), $5=$ patient sample (monoclone), $6=$ patient sample (polyclone).

\section{Author Details}

'Department of Clinical Pathology, Faculty of Medicine Siriraj Hospital, Bangkok 10700, Thailand and ${ }^{2}$ Department of Pathology, Faculty of Medicine Siriraj Hospital, Bangkok 10700, Thailand

Received: 22 December 2009 Accepted: 19 May 2010 Published: 19 May 2010

\section{References}

1. Wiangnon S: Lymphoma. In Chapter II-20. Cancer in Thailand. 1998-2000 Volume 4. Bangkok Medical Publisher. Bangkok. Thailand; 2007:66-67.

2. Sukpanichnant S: Analysis of 1983 cases of malignant lymphoma in Thailand according to the World Health Organization Classification. Human Pathology 2004, 35:224-230.

3. Trainor K, Brisco M, Wan J, Neoh S, Grist S, Morley A: Gene rearrangement in $\mathrm{B}$ and $\mathrm{T}$ lymphoproliferative disease detected by polymerase chain reaction. Blood 1991, 78:192.

4. Tai YC, Peh SC: Feasibility of T cell receptory (TCR y) gene rearrangement on formalin fixed paraffin embedded tissues by PCR assays. Singapore Med J 2003, 44:250-255.

5. Assaf C, Hummel M, Dippel E, Goerdt S, Muller HH, Anagnostopoulos I, Orfanos CE, Stein $\mathrm{H}$ : High detection rate of T cell receptor beta chain rearrangements in T cell lymphoproliferations by family specific polymerase chain reaction in combination with the GeneScan technique and DNA sequencing. Blood 2000, 96:640-646.

6. Kuo FC, Hall D, Longtine JA: A novel method for interpretation of T cell receptor $\gamma$ gene rearrangement assay by capillary gel electrophoresis based on normal distribution. J Molecular Diag 2007, 9:12-19.

7. Wood GS, Tung RM, Haeffner AC, Crooks CF, Liao S, Orozco R, Veelken $H$ Kadin ME, Koh H, Heald P, Barnhill RL, Sklar J: Detection of clonal T cell receptor gamma gene rearrangements in early mycosisi fungoides/ Sezary syndrome by polymerase chain reaction and denaturing gradient gel electrophoresis (PCR/DGGE). J Invest Dermatol 1994, 103:34-41.

8. Wittwer CT, Herrmann MG, Moss AA, Rasmussen TP: Continuous fluorescence monitoring of rapid cycle DNA amplification. Biotechniques 1997, 22:130-131.

9. Witter CT, Ririe KM, Andrew RV, David DA, Gundry RA, Balis UJ: The LightCycler: a mircovolume multisample fluorimeter with rapid temperuature control. Biotechniques 1997, 22:176-181.

10. Do H, Krypuy M, Mitchell PL, Fox SB, Dobrovic A: High resolution meling analysis for rapid and sensitive EGFR and KRAS mutation detection in formalin fixed paraffin embedded biopsies. BMC Cancer 2008 8:142-154.
11. Krypuy M, Newnham GM, Thomas DM, Conron M, Dobrovic A: High resolution melting analysis for the rapid and sensitive detection of mutations in clinical samples: KRAS codon 12 and 13 mutations in nonsmall cell lung cancer. BMC Cancer 2006, 6:295-306.

12. Nakao M, Janssen J, Flohr T, Bartram CR: Rapid and reliable quantification of minimal residualdisease in acute lymphoblastic leukemia using rearranged immunoglobulin and T cell receptor loci by LightCycler Technology. Cancer Res 2000, 60:3281-3289.

13. Gutzmer R, Mommert S, Kiehl P, Wittmann M, Kapp A, Werfel T: Detection of clonal $\mathrm{T}$ cell receptor $\gamma$ gene rearrangements in cutaneous $\mathrm{T}$ cell lymphoma by LightCycler polymerase chain reaction. J Invest Dermatol 2001, 116:926-932.

14. Dongen JJMV, Langerak AW, Bruggemann M, Evans PAS, Hummel M, Lavender FL, Delabesse E, Davi F, Schuuring E, Garcia-Sanz D, Bastard C, White HE, Spaargaren M, Gonzalez M, Parreira A, Smith JL, Morgan GJ, Kneba M, Macintyre : Design and standardization of PCR primers and protocols for detection of clonal immunoglobulin and T cell receptor gene recombinations in suspect lymphoproliferations: Report of the BIOMED-2 concerted action BMH4-CT98-3936. Leukemia 2003, $17: 2257-2317$

15. Dongsheng Xu, Du J, Schultz C, Ali A, Ratech H: Rapid and accurate detection of monoclonal immunoglobulin heavy chain gene rearrangement by DNA melting curve analysis in the LightCycler System. J Mol Diagn 2002, 4:216-222.

16. Kiyoi $\mathrm{H}$, Naoe $\mathrm{T}$ : Immunoglobulin variable region structure and B-cell malignancies. Int $\mathrm{J}$ Hematol 2001, 73:47-53.

17. Uemura A, Mori S, Sugahara K, Akamatsu N, Tsuruda K, Tsukasaki K, Hirakata Y, Atogami S, Hasegawa H, Yamada Y, Kamihira S: Rapid and high-resolution detection of $\mathrm{IgH}$ gene rearrangements using PCR and melting curve analysis. Int J Lab Hematol 2007, 29:200-207.

18. Retamales E, Rodriguez L, Guzman L, Aguayo F, Palma M, Backhouse C, Argandona J, Riquelme E, Corvalan A: Analytical detection of immunoglobulin heavy chain gene rearrangements in gastric lymphoid infiltrates by peak area analysis of the melting curve in the LightCycler System. J Mol Diagn 2007, 9:351-357.

19. Lyon E, Wittwer CT: LightCycler technology in molecular diagnostics. J Mol Diagn 2009, 11:93-101.

20. Wittwer CT: High-resolution DNA melting analysis: Advancements and limitations. Hu Mutat 2009, 30:857-859.

doi: 10.1186/1746-1596-5-31

Cite this article as: Kummalue et al., Detection of monoclonal immunoglobulin heavy chain gene rearrangement (FR3) in Thai malignant lymphoma by High Resolution Melting curve analysis Diagnostic Pathology 2010, 5:31 